\begin{tabular}{|c|c|c|c|}
\hline & \multicolumn{2}{|c|}{ R\&S - RESEARCH STUDIES ANATOLIA JOURNAL } & 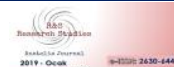 \\
\hline Research Studjies & www.dergipark.gov.tr/rs & Vol: 2, Issue: 4 pp: 83-100 & - \\
\hline
\end{tabular}

Ambaroğlu A, (2019). “20.yy Yahudi Düşüncesine Bir Katkı: Louis Jacobs (1920-2006)”, Vol: 2 Issue: 4 ; pp: 83-100

Anahtar Kelimeler: Yahudi Düşüncesi, İngiltere, Keywords: Jewish Thought, England, Louis Jacobs,

Louis Jacobs, Modernleşme, Muhafazakâr Yahudilik.

Secularization, Conservative Judaism.

Makale Türü Derleme

\title{
20.YY YAHUDİ DÜŞÜNCESİNE BİR KATKI: LOUIS JACOBS (1920-2006)
}

\section{A Contribution to 20th Century Jewish Thought: Louis Jacobs (1920-2006) \\ Ayșe AMBAROĞLU*}

Geliş Tarihi / The Received Date 16.01.2019
Kabul Tarihi / The Accepted Date 24.01.2019
Yayınlanma Tarihi / The Published Date 31.01.2019
ÖZ

20.yy, Modern Yahudi Teolojisi, Kurumsal Yahudilik, Modernleşme ve Dindarlık başta olmak üzere çok çeşitli alanlarda önemli tartışmaları kapsamaktadır. 17. Yy Erken Modern Dönem Aydınlanması, Aydınlanma Dönemi ve 19.yy Haskala hareketini takibeden 20 yy. Modern Yahudi düşüncesinde ilgiyi hakeden tartışmaları taşımada önemli bir rol oynamıştır. Louis Jacobs'ın görüşleri içinde eğitim aldığı İngiltere Yahudiliği 'nin aksine ABD ve Kanada da daha yaygın olan Muhafazakâr (Conservative) Yahudili k ile daha uyumludur. Louis Jacobs'ın eserlerinde Halakanın gelişimi, Kutsal Kitap metninin değerlendirilmesi, modernleşme karşısında birey ve dindarlık gibi 20. Yy Reform ve Muhafazakâr Yahudiligi nin önemli tartışmalarının etkisi görülmektedir. $\mathrm{Bu}$ çalışmada Louis Jacobs'ın görüşlerine dair genel bir bakış İngiltere Yahudiliği ve çağının problemleri açısından sunulmaktadır.

\begin{abstract}
20th Century Modern Jewish Theology includes important discussions a large variety of subjects mainly about Institutional Judaism, Modernization and Religiousness. Following 17th century Early Modern Enlightenment Era and the 19th century Haskalah movement played an important role in 20th century Modern Jewish thought by supporting attention provoking discussions. Contrary to British Judaism which he got educated in, Louis Jacobs's perspective is more compatible with Conservative Judaism which is more prevalent in USA and Canada. Important discussions of 20th century Reformist and Conservative Judaism such as development of Halaska, interpretation of Holy Book, individual against modernization and religiousness can be followed in his writings. In this work, a general look on Louis Jacobs' thoughts is presented regarding British Judaism and problems about its era.
\end{abstract}

ABSTRACT

\section{GíRiş}

Muhafazakâr (Conservative) Yahudilik, 20. yüzyıl Modern Yahudi Hareketleri içinde kurumsal gelişimini büyük ölçüde Amerika Birleşik Devletleri'nde tamamlamıştır. Muhafazakâr (Conservative) Yahudilik: Kurucusu Solomon Schechter (1847-1915) olarak kabul edilen, Yahudi toplumunun bütüncüllügünü ve tarihi sürecin kademeli olarak değișiminin varlığını ve gerekliliğini savunan modern Yahudi akımıdır. İngiltere Yahudiliğine özgü adıyla 'Masorti hareketi' olarak anılmaktadır. Solomon Schechter (ö. 1915) tarafından 'Katolik İsrail' olarak formüle edilen Muhafazakâr Yahudilik, geleneğin devamlılığı ile modernizmin kaçınılmazlığının uzlaşısının imkan ve gerekliliğini ifade etmektedir (Gürkan, 2008;45). Amerika ve Kanada'da 'Conservative Judaism'olarak isimlendirilen Muhafazakâr Yahudilik, Yahudi grupları içinde nüfus bakımından Amerika Birleşik Devletleri'nde Ortodoks Yahudilik'ten sonra ikinci sırada yer almaktadır. İngiltere'deki Yahudiler arasında ise Muhafazakâr Yahudilik, en az nüfusa karşıllk gelmektedir, bu da verilerine göre, 2016 yllı İngiltere'deki Yahudi nüfusu 290 bin olup, yaklaşık \%5 ile en küçük Yahudi Topluluğuna karşılık gelmektedir (www.jewishvirtuallibrary.org/jewish-population-of-the-world, 2016). 
'Kutsal Kitab'ın Yasa oluşu (Tekrarı \& 31:24-26)','Yahudiler' in seçilmiş topluluk oluşu (Tekrarı \& 3:6)', 'ahit kanunu (Yaratılış \& 17:1-9)' başta olmak üzere, dini ve kültürel olarak Yahudilik geleneğinintemel doktrinlerinin hem Kutsal Kitap metin incelemeleri ve yorumlamaları ile hem de Yahudiliğin tarihi dönüm noktaları ile ilişsilendirildiği çalışmalar mevcuttur.

Yahudilik tarihinde; İbrahim ve Musa peygamberlerle, monoteist inanç temel bir prensip olarak kesinlik kazanmıştır (Vogel, 1978). Tevrat'a göre Tanrı, İsrail toplumu ve İsrailoğulları́nın peygamberleri ile anlaşmalar yapmıștır (Weinfeld). İbrahim Peygamberin Harran'dan, Kutsal Toprak olarak belirtilen Kenan ülkesine, ailesiyle birlikte göç etmesi de Tanrı'nın İbrahim peygamber ile yaptığı anlaşma sonucu gerçekleşmiştir (Yaratılış \& 12:1-5). İbrahim Peygamber'in bu emri yerine getirmesi, hem dini yükümlülük hem de Yahudilik için mekan ve toplumla ilişkili yeni bir dönüm noktasına karşıllk gelmektedir. Böylece, Kenan bölgesi İsrail topraklarına dönüșmekte, farklı iki toplum İsrail halkı ile Kenan ülkesi halkları arasında toplumlararası bir ilişki kurulmaktadır. Yahudilik'te mekân, toplum ve din ilişkisi döngüsel bir karakter taşımakta olup, Kutsal Kitap ve Yahudi geleneğinin oluşumunda olduğu gibi modernleşme sonrası XX. yy Yahudi hareketlerinde de bu konunun tartışılmasına devam edildiği görülmektedir.

Babil Sürgünü öncesi ve sonrasındaki gelişmeler Yahudilik dininin sosyal bir yapı olarak kurumsallaşması, geliştirilmesi ve sonrasındaki diaspora tecrübesi açısından önem taşımaktadır. İkinci Mabed Dönemi'nde Yahudiler'in, Babil'den Kudüs'e geldikten sonra, M.Ö. 516-515'te mabedi yeniden inşa etmeleriyle başlayıp, Mabed'in Romalılar tarafından M.S. 70 yılında yıkılışına kadar olan dönemdir (Kurt, 2015;945). İkinci Mabed Dönemi özellikleri, etnik yapı vurgusunun devamı, toprak yerine soyun ön plana çıkarılması, liderliğin Davudoğulları'ndan kahinlerin eline geçmesi, Tora'nın yazıya geçirilmesi, İsrail sınırlarının belirlenmesi ve yeni bir çağın (eskatolojik) başlaması olarak kabul edilebilir (Kurt, 2015;945). Yahudiler'in İspanya'dan 1492 yılındaki sürgünüsonrası dönem ise, toplumsal hareketliliğin kültürel çalışmalara etkisi ile Erken Modern Dönem Yahudiliği ve Haskalanın hazırlayıcısı olma niteliğini taşımaktadır (Ruderman, 2010). Modern Yahudi Tarihinde ise, İspanya Sürgünü sonrası, ondokuzuncu yüzyıl Haskala Hareketi ve İkinci Dünya Savaşı sonrası gelişen Yeni Yahudi Teolojisi dönemleri özellikle dikkat çekmektedir (Robert).

Hıristiyan Reformu sonrasında Kutsal Kitap metninin kurumsal olarak değil bireysel olarak da yorumlanmasının yaygınlaşması Haskala döneminde Yahudilik'in Kutsal Kitap'ın felsefi, teolojik, eğitim ve ritüellerle ilgili yorumlarının tartışılması, Almanya'dan başlayıp Avrupa'daki diğer ülkelere yayılmıştır. XVIII. yy. ve sonrasında Yahudi nüfusunun, Avrupa'da önce Almanya ve İngiltere'ye, daha sonra Birinci ve İkinci Dünya Savaşı koşulları nedeniyle; Amerika Birleşik Devletleri ve Kanada'ya yaşanan göçler yönündeki (Ettinger, 1997, 860) değişimi Modern Yahudi hareketlerinin karakteri üzerinde etkili olmuştur.

XX. yy. Yahudi yaklaşımlarından özellikle Reformist-Liberal Yahudilik (Jacobs, The Jewish Religion: A Companion, 1995,417), ve Louis Jacobs'ın fikren uyum içinde bulunduğu Muhafazakâr Yahudilik hareketleri içinde haskala sonrası sekülerleşmenin getirdiği problemlerin felsefi ve pratik olarak nasıl aşılacağı, modernleşme sonrası genel teolojik yorumlamanın nasıl olması gerektiği, Yahudilik'in temel prensipleri yeniden tartışılmış ve yorumlanmıştır. İsrail Devleti'nin kuruluşu, öncelikle modernleşmeyle ilişkilendirilse de Post-modern yaklaşıma göre, dini esaslara göre Yahudilik içindeki dönemsel farklılaşmaların, kurumsallaşma konusundaki etkisini gösteren bir örnektir (Petuchowski, 23-27).

Reformist-Liberal Yahudilik, Alman Rabbiler tarafından 1885 Pittsburgh Platformu ile Ortodoks Yahudiliğin vahiy (Lipinsk, 118-119) düşüncesinden ayrılarak oluşan akımdır. Reformist Yahudilik, başlangıçta Siyonizm'e karşı olmasına rağmen zamanla Siyonizm'e yaklaşan görüşler taşımaktadır. Kutsal Kitap eleştirilerinin bilimsel metotlarla yapılması ve bu doğrultudaki çalışmalar ışığında yorumlanması gerektiğini savunan Reformist Yahudiler, Halaha'nın ortaya çıkışının Rabbilerin tartışmaları sonucu oluşmasının metot olarak kendilerine örnek olduğunu ifade etmişlerdir. Başlangıçta ilerlemeye açık, yenilikçi kabul edilen ve Reformist Yahudiler ile birlikte hareket eden Muhafazakâr Yahudilik'te yer alan düşünürler, daha sonra geleneğin devamlılığı ve yiyecek yasakları konuları başta olmak üzere, görüş ayrılıkları nedeniyle 1886 yılında Jewish Teologycal Seminary'yi (JTS) kurarak ayrışmışlardır. Robert G. Goldy'ye göre Yeni Yahudi Teolojisinin temelinde İskenderiye, 
Orta çağ İspanya ve Modern Almanya'daki Yahudi olmayan kültürlerle olan etkileşimler önemli bir yere sahiptir (Robert, 1990, 7). Goldy'nin bu tesbitiyile Emilie Durkheim'in (1858-1917) toplumsal olaylar analojisinin özelde Yahudilik açısından taşıdığı benzerlik, modernleşmenin dini kurum, teoloji ve pratikler üzerindeki etkisinin araştırılmasının önemini göstermektedir. Durkheim'e göre toplumsal olaylar arasındaki nedensellik ilișkisinin varlığı (Durkheim, 1995, 24-25) dinlerin incelenmesinde beşerî, çevresel, sosyo-ekonomik koşulların etkinliğinin soyutlanamayacağını bilakis bu çerçeve içinde incelenebileceğini söylemek mümkündür. Louis Jacobs'ın Kutsal Kitap'ın oluşumundaki çevresel koşulları vahyi birlikte değerlendirmeye alması ile, Holokost felsefe ve teolojisindeki, Emil Fachenheim, Richard Rubenstein gibi düşünürlerin (Katz, 1975, 223) Yahudiler'in İspanya (1492), Almanya (1941-1944) başta olmak üzere soykırım konusunu Tanrı ve kötülük bağlamında ele alması, Yahudilik ile ilgili araştırmalarda yöntem farkının önemini ve dönemsel gelişmelerle yeni yorumlama biçimlerini ortaya çıkarmaktadır (Katz, 1975, 228).

\section{2. İNGILLTERE'DE YAHUDİLIKK}

Yirminci yüzyılın dine bakışı, İngiltere Yahudiliği'nin genel durumu, Ortodoks-Liberal ayrışması, eleştirel görüşlerin Louis Jacobs tarafından nasıl yorumlandığı, sonuçları açısından oldukça önemlidir. Jacobs, Londra merkezli Birleşik Ortodoks Yahudileri'ne ait New West End Sinagogu'nda hahamlık görevini sürdüren bir Rabbi iken, 1957 yılından itibaren Jewish Chronicle'da (Ceserani, 2005, 217) yayınlanan ve daha sonra 'Jacobs Affair' olarak isimlendirilen Kutsal Kitap ve vahiy konusunda Ortodoks Yahudi düşüncesinin dişında kabul edilen görüşleri nedeniyle eleștirilerek, dışlanmıștır. Bahsedilen bu yazılar daha sonra, Louis Jacobs'ın Kutsal Kitap ve vahyin içeriğine dair temel görüşleri olarak 'We Have Reason to Believe' isimli eserinde yayınland. 'We Have Reason to Believe' Louis Jacobs'ın yayınlanan ilk eseri olup, Kutsal Kitap metninin beşerî ve çevresel unsurlarla vahyin sentezini içerdiğini kabul etmek gerekliliğini savunmakta, modern Kutsal Kitap eleştirilerini dikkate almaktadır. Ortodoks Yahudilik'in vahiy görüşlerinin dışında eleştirel bir bakış açısını kazanması, açıklamalarını Ortaçağ ve Çağdaş Felsefi görüşlerle açıklaması bu çok yönlü Rabbi hakkında çeşitli alanlarda çalışmaya imkan sağlamaktadır.'We Have Reason to Believe' eserindeki görüşleri nedeniyle Hahambaşı olmaktan menedilen (Brook, 1989,116), heretik olmakla suçlanan ve Ortodoks Yahudi geleneğine karşı çıkmakla suçlanan Louis Jacobs, görüşlerini teoloji, etik, hukuk, mistisizm başta olmak üzere çeşitli alanlarda sürdürmüştür.

Yirminci yüzyılda dinin gerilemesi veya yokolması tezi çevresindeki felsefi ve sosyolojik tartışmalar, Yahudilik içinde de farklı boyutlarıyla değerlendirilmiştir. Louis Jacobs, Yahudi geleneğini eleştirel olarak analiz ettikten sonra, geleneksel kimlik kabulünün önemini daha da pekiștiren Muhafazakâr Yahudilik ile uyumlu bir şekilde, Yahudilik dininin kültürel gelenek ve dini kimliğinin reddedilmeden, günün koşullarına uygun metotlarla gözden geçirildikten sonra kamusal devamlılığının sağlanmasını savunmaktadır.

Yaklaşık üç bin beş yüz yıllık bir tarihe sahip olan Yahudilik'in varlığını koruması güçlü bir gelenek sayesinde mümkün olmuştur. Dinin felsefi ve doktrinsel boyutu ile bireysel tecrübe ve toplumsal bir olgu boyutnu ayırt edilebilir alanlardır. Bu çalışmanın amacı, felsefi ve doktrinsel içerik ile bireysel, toplumsal bir olgu arasındaki yorumların değişkenliğini etkileyen din dışı koşulların bu iki alan arasında nasıl ilişki kurduğu ve dini geleneği oluşturan bu ilişkinin hangi koşullarla devam ettiğini sorgulamaktır. Din, felsefi-teolojik, etik-ahlaki ve hukuki-pratik, ana bileşenlerden oluşan bir sosyal kurumdur. Sosyal kurumlar da organizmalar gibi varlıklarını koruma ve devam ettirme eğilimindedir. Dinler kendilerine inanan topluluk olduğu sürece, yaşamla ilgili tehdit kabul edilen koşullara karşı refleks sahibidir.

Sekülerleşme kavramına modernleşme sonrasına ait olma anlamı yüklense de bu kavramın dönemsel bir kavram olmadığını kabul eden Talal Asad'e göre, 'dini' ve 'seküler' temel olarak sabit kategoriler değildir. Seküler kabul edilen kurumların üzerindeki örtüleri kaldırdığımızda aslında dini olduklarının anlaşılacağını iddia etmediğini belirtir. Asad'a göre, hiçbir şeyin özünde dini olmadığını ve de 'kutsal dili' ya da 'kutsal deneyimi' tanımlayan evrensel bir öz olmadığını savunur (Asad, 2007, 38). İnsanlar, üzerinde düşündükleri her şeyin gerçek ya da ideal iki sınıfa ya da iki gruba ayrıldığını varsayar. Bu sınıflama genellikle dünyanın, biri kutsal diğeri din dışı olan iki alana bölünmesi anlamına gelmektedir (Asad, 2007, 38). 
Mircea Eliade (1907-1986) ise fenomenolojik olarak Dinler Tarihi'nin bir yorum olduğunu belirtir, kutsal-kutsal dışı ikileminin evrendeki diğer çift kutuplu kavramlardan -kadın-erkek, yer-gök gibi- ve kutuplaşmalardan farklı olarak zıtlaşma içermediğini ifade eder. Eliade'e göre, kutsal olanın yorumu, kutsal dışı kabul edilenin de anlaşılması ve yorumlanmasına kapı aralamaktadır. Bizzat din kavramı ile ilişsili olmak demek, dindışı olanla da karşı karşıya kalmak demektir (Eliade, 2000, 6). Bu durum ilk akla gelenin aksine, kavramsal bir rekabet ve zıtlığın olmadığı anlamına gelmektedir.

Eliade'e göre, Dinler Tarihi, kültürel bir disiplin olarak, İlahiyat dışındaki kültürel unsurlar arasındaki farklılaşma, değişme ve tedrici olarak gelişen kabul süreçlerini de içermektedir (Eliade, Dinin Anlamı ve Sosyal Fonksiyonu, 68). Mircea Eliade'e göre, mit kavramını kabul ettiğimiz andan itibaren, inanç ve bilgi, akıl ve hayalgücü, tarih ve kurmaca, simge ve alegori, doğal ve doğaüstü, kutsal ve dindışı gibi, modern-seküler söylemi çağrıștıran kavramlarla da karşı karşıya kalırız (Eliade, Dinsel İnançlar ve Düşünceler Traihi, 2000, 6). Louis Jacobs ise din tarihçisi ile ilahiyatçının işlevleri yönünden karşılaştırıldığında; din tarihçisinin geçmişte tam olarak ne olduğunu, ilahiyatçının ise geçmişte olanların doğruluğundan ziyade günümüzdeki inanca etkisinin nasıl olduğunu incelediğini belirtmektedir (Jacobs, Beyond Reasonable Doubt, 76).

Louis Jacobs'ın eserlerinde genel özellik yukarıdaki ilkenin gereği ve sonucu olarak ilahiyatçı bakış açısını görmek mümkündür.

Yahudilik Tarihi içinde-örneğin sürgün ve göç koşullarında- farklı sosyal düzenlemelerdeki değişikliklerin, dini gerekçelendirmelerle ilişkilendirilebilmesi yetersiz kalmaktadır. Louis Jacobs'ın geleneğin tümden reddedilmemesi anlayışı ile Talal Asad'ın dini veya dini olmayanı tanımlamanın nesnel bir kategorilendirmeye dayanmadı̆̆ı düşüncesi, Jacobs'a göre Yahudilik, Asad'a göre ise, Yahudilik, Hıristiyanlık ve İslam başta olmak üzere diğer dini gelenekler üzerinde dindışı koşulların etkisini vurgulamaktadır. Çünkü Louis Jacobs'ın çalışmalarında dindar bir Yahudi olmanın ötesinde, haham ve akademik kimliği ile, Yahudilik'in tarihi, kültürel, ekonomik ve modern etkileşimlerle vahyin içiçeliğini kabul etmenin olumsuzluk içermediği fikrinin temel olduğu görülmektedir (Jacobs, We Have Reason To Believe, 14).

\section{LOUIS JACOBS (1920-2006) HAKKINDA}

Louis Jacobs'ın hayatı, görüş ve eserlerini konu alan, Elliot Joe Cosgrove tarafından 'Teyku: Unsoluble Contradictions in The Life And Thought Of Louis Jacobs' adıyla hazırlanan doktora tezi (Cosgrove) ve Louis Jacobs'ın eşinin arşivinden kendisinin derleyerek kaleme aldığı otobiyografisi 'Helping With Inquiries (Jacobs, Helping With Inquiries: An Autobiography, 1989)', hayatı hakkındaki verilerde kaynak olarak kullanıldı.

Louis Jacobs'ın 'vahiy' kavramının içeriği hakkında Louis Jacobs'ın 'We Have Reason To Believe' eserindeki temel görüşlerinden yola çıkılarak Yahudiliğin geleneksel vahiy anlayışındaki problem, 'Jewish Law', 'A Tree of Life', 'The Talmudic Arguement' eserlerindeki, Kutsal Kitap eleștirileri, geleneksel yorumların değerlendirilmesi, insani ve sosyal şartların gözardı edilemeyeceği durumlar, geleneğin özünün korunabilme koşulları dikkat çekmektedir. Çünkü hukuk; kamusal ve bireysel açıdan taşıdığı normatif değerlerle temsil edilmektedir. Dinin hukuki anlamda taşıdığı değerlerin ve vahyin normatif hükümlerinin kaynağının İlahi, beşerî, sosyo-ekonomik etkenlerinin nasıl birbirini etkilediği ve bu durumun anlaşılabilmesi için nasıl ayrıștırılacağı ile ilgili sorular Yahudi hukuku açısından da önem taşımaktadır.

Louis Jacobs adını taşıyan web sayfası http://www.louisjacobs.org halen aktif durumdadır. Oxford Üniversitesi, Boudlein Kütüphanesi'ne bağlı bir birim olan ve Avrupa Yahudileri'nin ortak çalışma platformu olarak faaliyet gösteren European AssosiationJews Studies'de (EAJS) bulunan, Jewish Studies Library'de, Louis Jacobs'ın şahsi kütüphanesi, eserleri, fotoğraf ve hakkındaki digital veriler yer almaktadır.

İkinci Dünya Savaşı sonrası, Reformistlere mesafeli duran, Reconstructionist (Yeniden Yapılanmacı) harekete oranla, Ortodoks Yahudilik'e daha yakın bir çizgide olan Louis Jacobs'ın, Yahudilik ile ilgili her alanda eser vermiş olması, Muhafazakâr Yahudilik hakkındaki eleștirilerin kendisine de yöneltilmesine neden olmuştur. Geleneğin sürekliliğini savunmak ile vahiy ve Kutsal Kitap görüşünün tutarlı olmadığı bu eleştirilerin en başında gelmektedir (Wertheimer, 2007). Louis Jacobs'un Tevrat'a 
bakışında, Rabbani geleneği saygılı bir şekilde incelediği görülmektedir. Louis Jacobs'ın Yeşiva sonrasında Tevrat hakkındaki çalışmalarına devam etmesi, Londra Üniversitesi'ndeki doktora eğitimi sırasında edindiği felsefi birikim, Babil Talmudu hakkındaki araştırmaları ve Yahudilik'in güncel problemleri karşısında Amerika'daki Muhafazakâr ekol ile olan fikri uyumu dikkat çekicidir.

Yahudi din adamları için, Kutsal Kitap'ın orjinalliği ya da içeriğindeki anlatımın sembolik olup olmadığı tartışmasının temel bir tartışma olduğu görülmektedir. (Bağır)

Dinin kurumsal olarak eleştirisi, XX. yy. sınırlarında ve Yahudilik özelinde toplumsal hayatta nasıl bir karşılık buldu? Bireysel dindarlık, yeni dini hareketler bu konuda oldukça önemli sorgulama ve çözümlemeleri bugüne taşımıştır. Dinin metin ve doktrini arasındaki ilişki, birbirini tamamlar ve ayrılamaz gibi değerlendirilir. Yahudilik için, Kitab-1 Mukaddes'in oluşumu göz önüne alındığında, insan unsurunun, metin üzerindeki etkisi yadsınamaz.

İngiltere'deki Yahudilik'in hangi etkenlerle biçimlendiği ile ilgili, Geoffrey Aldermann'ın 'London Jewry And London Politics, 1889-1986 (Alderman, London Jewry and London Politics 1889-1986, 1989)', Todd Endelmann'ın 'The Jews of Britain 1656 to 2000', David Ruderman'ın 'Erken Modern Dönem Yahudi Tarihi', Cecil Roth'un, 'A History Of The Jews In England' ve Bernard Martin'in 'A History of Judaism' eserlerinden bahsedilebilir.

Louis Jacobs'ın Yahudi Teolojisini açıkladığı ‘A Jewish Theology' eserinde ise, inanç konusundaki bakış açısını hangi temellere dayandırdığı ve Ortodoks Rabbi geleneği eğitimi almış olmasının gereği olarak ilgili konulardaki tartışmaların ana çizgisini takip ettiği görülmektedir. Louis Jacobs, Yahudi Teolojisi ve Kutsal Kitap ile ilgili konularda Orta çağ Yahudi Bilginleri; Sadia Gaon (882-942), Abraham b. Azra (1089-1167) ve Maimonides (1135-1204)'in özellikle teolojik görüşlerine eserlerinde sıkça yer vermiştir.

\section{MODERN DÖNEM VE YAHUDILLER}

İspanya'da yaşayan Yahudiler'in karşı karşıya kaldığı zorlu koşullar sonrasında XVI. yy. boyunca İber Yarımadası'ndaki Yahudi toplulukları Osmanlı Devleti himayesinde İstanbul, Simirna ve Selanik başta olmak üzere güvenli bölgelere yerleştirildiler. Onyedinci yüzyılın ikinci yarısında Mesih hareketi ve mistisizmin merkezi olan Safed, Kabala öğrenimi için önemli bir merkez haline geldi (Spiro, 1992). İspanya'dan çıkarılmalarından sonra Yahudiler kıymetli hazineleri Zohar'ı, önce Türkiye, Filistin, Mısır'a daha sonra ise İtalya, Almanya, Hollanda ve İngilyere'ye taşıdılar. Sayılan tüm ülkelerde Zohar'ın öğretimi yeni yorum ve derinliklerle genişlemeye devam etti. Filistin'deki Safed kenti diğerlerinden farklı olarak Zohar öğretiminde en yüksek seviyeye ulaştı. Louis Jacobs'ın çevirisini yaptığı Moses Cordovero (d.1522), Safed'deki mistisizm okulunun önde gelen uzmanlarından kabul edilmektedir. Safed Sabatay Sevi'nin doğum yeri olarak kabul edilmektedir.

Yahudi aydınlanması anlamında kullanılan, 'Haskala' genel olarak, Avrupa Aydınlanma Hareketi'nin karşılığı olan ve bazı ülkelerde Yahudilerin gettolardankurtulması ve Avrupa topluluğuna katılmasına izin veren liberal yasaların yürürlüğe konulmasıyla başlayan, XVIII ve XIX. Yüzyıllardaki Yahudi aydınlanması anlamında felsefî ve sosyal bir harekettir. En dar anlamıla önce Almanya'da, ardından Doğru Avrupa'da İbranice metinler ile filoloji üzerine çalışan ve öncü; 'maskilim' olarak adlandırılan Yahudi aydınları hareketidir. En geniş anlamıyla, Yahudiler'in gettolardan çıkıp seküler Avrupa toplumuna katılmasını savunan tüm akımlar, haskala hareketini ifade eder (Kurt, Yahudi Aydınlanma Hareketi Haskala, 2010). Reformun Yahudiler üzerindeki etkileşimi ile ilişkilendirebileceğimiz Haskala, Kutsal Kitab üzerinden yenilikçi ve dönüştürücü bir karakter taşımaktadır. Aslında Haskala öncesi, 1492 İspanya Sürgünü Avrupa Yahudileri'nin yaşamındaki sarsıntı, takip eden Portekiz ve İngiltere olayları, Reform ve Fransız İhtilali'nin sonuçlarının Yahudi Aydınlanması'nın hazırlayıcı etkenleri arasında olduğu görülmektedir. Avrupa Yahudileri'nin rasyonalist arayışları, Yahudi Modernleşmesi üzerine çalışan başta Yahudi tarihçileri ve düşünürlerinin üzerinde durduğu; teolojik, tarihi, felsefi ve sosyolojik olarak önemli problem ve açıklamalar ile karşımıza çıkmaktadır.

Haskala'nın Almanya merkezli etkisi, özellikle Birinci ve İkinci Dünya Savaşı sonrasında hızlanan göç dalgası ile birleşerek, başta İngiltere ve diğer Avrupa ülkelerine daha sonra da Amerika Birleşik Devletleri ve Kanada'ya taşındı. Göçler, hem ekonomik ve sosyal yaşam koşullarındaki düzen sorunu için alternatif oluşturmuș, hem de entelektüel olarak yetişmiş Yahudi bilginlerinin kendilerini daha özgür koşullarda ifade etmelerine imkân sağlamıştır. Göç hareketlerinin yoğunlaştığı dönem olan 1492 
İspanya Sürgünü nüfus hareketliliğinin sonuçları nedeniyle Yahudi Modernleşmesi açısından önemli bir tarihtir (Ruderman, 2010, 145). Buna rağmen 1492 öncesinde de Aşkenazi grupların Almanya'ya doğru göç hareketi içinde oldukları bilinmektedir. Bu arada, İtalya, Almanya ve Hollanda'ya doğru olan göçlerin aynı zamanda Protestanlık hareketinin de merkezi ve yoğun olduğu bölgeler olması dikkat çekicidir. Çünkü, Protestanlık, Yahudi Kutsal Kitabı'nı Yahudiler'in kabul ettikleri kısmıyla kabul etmiş, İbranice öğrenimini destekleyerek, Katolikliği eleştirirken, dinin özü ile ilgili argümanlarını Eski Ahid ile destekleme çabası içine girmiştir. Yahudiler'in Rönesans ve Reform üzerindeki etkilerinin pek az olduğu tezini yetersiz gören David B. Ruderman bu konuda yeterli çalışma olmadığına dikkat çekerek özellikle İtalya'da az sayıda da olsa etkin entelektüel Yahudi topluluğunun varlığını belirtir. Ruderman'a göre bu dönemde Yahudiler, Avrupa'nın İtalya, Avusturya, Macaristan, Hollanda başta olmak üzere başlıca merkezlerinde, hümanist, Aristocu ve Neo-Platoncu sınıflar bağlamında kültürel izler bırakmışlardır (Ruderman, 2010, 145).

Haskala Dönemini ya da Yahudi Aydınlanma tarihini iki farklı dönemde incelemek gerekir. 1720-1770 yılları arası, İlk Haskala Dönemi, 1780 ve sonrasına denk düşen dönem ise, Haskala Dönemidir. Yahudi Aydınlanmasının ilk döneminde, dini ve entelektüel görünüş, ikinci dönemde ise, sosyal ve siyasi bir görünüş vardır. Avrupa'da eğitimli, entelektüel ve dini vurguyu sürdüren Aydınlanma yanlısı Yahudiler'in sürdürdüğü gezginlik faaliyetleri, Moses Mendelssohn'un da aralarında bulunduğu bir şekilde dini ve entelektüel bir harekettir. Mendelssohn'un öğrencilerinde ise, sosyal, siyasi, ideolojik hareket belirginleşmiştir (Jonathan, 1998, 12).

Haskala öncesi dönemde bile Yahudiler'in içinde bulundukları toplumların ticari ve entelektüel alanlarında kendilerinden söz ettirmeleri ve Hıristiyanlık içindeki reform sonrası hareketlilikten de etkilenerek, uzlaşmacı ve laik bir toplum konusundaki görüşlerinin belirginleştiği görülmektedir. Bu konuda 'Yahudi kültürünün hangi konularda Avrupa toplumundaki eğilimlerle uyum içinde olduğu sorusuna yanıt arayan Jonathan Israel için, Yahudilik'in farklı toplum ve kültürleriyle beslenerek oluşan bir topluluk olmasının önemli bir etken olduğunu belirtmektedir (Jonathan, 1998, 12). David B. Ruderman'a göre, J. Israel'in bahsettiği bu etken aynı zamanda Yahudiler için birlikte yaşadıkları toplum için entelektüel alana çekilmenin kaçınılmaz bir sonuç olduğunu göstermektedir (Ruderman, 2010, 159). Bu yorum, vatandaşlık hakları konusunda Yahudiler'in karşılaștığı problemlerin genel bir sonucu olarak görülebilir.

Kutsal Kitap eksenli düşünceler arasında İbranice'nin ibadet dili olarak zorunlu olmaması, Kutsal Kitap vahyi ve yorumlama geleneği ile ilgili eleştirilerin daha fazla dile getirildiği Yahudi aydınlanması (Haskala), Yahudi kimlik, din ve bilincinin, sadece, inanç ve ibadet boyutunu değil, felsefi, sosyolojik boyutunu da tartışarak, farklılaşmalar kadar, çözüm arayışlarının da açığa çıkmasını sağlamıştır.

Spinoza'nın Tevrat eleştirisi, Yahudi Kutsal Kitabı ile ilgili önemli bir dönüm noktası oluşturarak, kendisinden sonra bu konuda araştırma yapanlar için bilimsel metodik eleştiriyi benimsetmiştir. Spinoza'nın yönteminden etkilendiğini belirten Richard Simon (1638-1712), Tevrat'taki ilk beş kitap ile ilgili, üslup farklılıkları, yazar farklılıkları, konuların anlatımındaki çelişsiler ve Tevrat'ın Musa tarafından yazılmadığını belirtmiştir (Hazard, 1999, 111). Wellhausen (ö.1918) öncesinde yaz kimler olduğunu ve O'nunla devam eden Kutsal Metnin oluşumu konusundaki teorilerde, peygamber dışı unsurlar yani kohenlerin yasa koyma geleneğinin net bir bilgi olarak kabul edilmesinin zorunluluğu sonucu Musa Peygamber'e nisbet edilen ilk beş kitabın, Musa tarafından yazıldığı bilimsel olarak iddia edilemez (Friedman, 2004, 38).

1492 İspanya başta olmak üzere ve Avrupa'nın diğer bölgelerinde görülen Yahudiler'e yönelik dini soykırım, baskı ve anti-semitizmi doğuran uygulamalar, Almanya'da holokost başta olmak üzere; Yahudiler'e özel sonuçları taşıyan bu gelişmeler yanında, dünyada din felsefesi alanındaki tartışmalar, dinin nesnelliği, sekülerleşme başta olmak üzere Yahudiler'in de katkı sundukları ve toplumsal olarak etkilendikleri süreçler olarak karşımıza çıkmaktadır.

\subsection{Modern Yahudi Teolojisi}

XX. yy. Modern Yahudi Hareketlerinin Amerika Birleşik Devletleri ve Kanada merkezli Reformist ve Liberal oluşumlarolarak netleştiği bir döneme karşılık gelmektedir. Fakat bu durum anti-tezleri deüreterek Yeni Yahudi Teolojisi'nin bireysel dini tecrübeden kurumsal eleştiriye, varoluşçuluktan, 
Post-Modern tezlere kadar geniş bir yelpazeyi içermektedir. Yeni Yahudi Teolojisi (New Jewish Teology), yirminci yüzyılın ilk yarısında yaşanan iki büyük dünya savaşı ve buna bağlı koşullardan bağımsız olarak anlaşılamaz. Ayrıca Yahudiler'in Avrupa'dan Amerika'ya olan göç hareketindeki ivme, Amerikan Devlet yapısındaki özgürlükçü ve demokratik eğilimlerin oluşturduğu akademik ve entelektüel çeşitliliğin Louis Jacobs örneğinde Ortodoks Yahudilikteki dışlanmasının ardından Amerika Birleşik Devletleri'ndeki Jewsih Theologycal Seminary ile bağ kurarak görüșlerini daha geniş kitlelere duyurmayı başardığı görülmektedir.

XX. yüzyılın diğer önemli düşünürleri Hermann Cohen (1842-1918), Franz Rosenzweig (1888-1929), Leo Beack (1873-1956) Martin Buber (1878-1965) ve Mordecai Kaplan (1881-1983), olmak üzere; Tanrı merkezli ve kurumsal eleștirel kabul edilen görüșlerinin yanısıra, Abraham Jashua Heschel (1907-1972), Milton Steinberg (1903-1950), Emil Fackenheim (1916-2003), Jacob Josefh Petuchowski (1925-1991), Joseph B. Soloveitchik (1903-1993), Will Herberg (1901-1977), Eugene B. Borowitz (1924-2016), Robert Gordis (1908-1992), Arnold J. Wolf (1924-2008) gibi düşünürler insan merkezli eleștirel görüşleri ile 1950 li yıllarda Yeni Yahudi Teolojisinin gelişmesine katkı yapmışlardır.

\subsection{Ingiltere'de Yahudi Yerleşimi}

Roma İmparatorluğu'nun o zamanki genel ismiyle Suriye Bölgesini işgali sonrasında, Yahudiler atalarının toprakları dışında yaşamaya, diaspora hayatına mahkûm oldular ve yaşadıkları bölgelerdeki kültürel yoğun baskılara katlanmak durumunda kaldılar. Bu dönemde Yahudiler'in tarım toplumu olma özelliğini devam ettiren Filistin ve Mezopotamya'dan tedrici olarak ayrilmaya mecbur bırakılarak, dünyanın birçok farklı bölgesinde yaşamaya zorunlu olarak başladıkları görülmektedir. Yaygın Hıristiyan kültürünün ve sosyo-ekonomik koşulların Yahudiler'in yaşam becerilerinde yenilikler geliştirmelerini ve sınırlı, özel koşullarda dini inançlarını koruyarak varlıklarını koruyarak devam ettirmelerini sağlamıştır (Roth, A History of The Jews in Britain, 1942, 14).

İngiltere, Yahudiler'in Orta çağ sonuna doğru ve Avrupa'da en son yerleştikleri ülkelerdendir. Ticari yetenekleri ve uyumlu sosyal davranışlarıyla Yahudiler İngiltere'de saygınlı ve zenginlik kazanmalarına rağmen, 1222'deki 4. Lateran Konsili sonrası ayrımcılık ile karşı karşıya kaldılar. Bu durum Avrupa'nın diğer bölgelerindeki uygulamalar ile karşılaştırıldığında oldukça erken bir döneme rastlamaktadır.

1492 İspanya Sürgünü ve sonrasında Yahudiler için, İspanya ve Portekiz Yahudileri için Akdeniz çevresindeki adalar ve onların bağlı olduğu İstanbul (Osmanlı Devleti) güvenilir alanlar haline geldi. Kasım 1655'deki Whitehall Konferansı'ndan sonra Yahudiler'in İngiltere'de yaşamalarına müsaade edilmesine karar verilmiştir. İngiltere'de gettolarda yaşayan Yahudiler'in güvensizlik ya da yaşam tehdidi ile karşılaşmadıkları belirtilmektedir. XVII. yy. ortalarında ise, Londra'da Marranolar koloniler halinde yaşamaya başladılar (Salihoğlu, 2011, 105-115). Amerika Birleşik Devletleri'ndeki Yahudiliğin Menessah Ben Israel (1604-1657) olayı yüzünden sorgulanması, İngiltere Yahudiliği için de statü kaybına neden olmuş, Avrupa'nın diğer bölgelerinden daha az haklara sahip bir topluma dönüştürmüştür. Buna rağmen İngiltere ve İrlanda, Kuzey Avrupa'ya doğru Yahudiler'in göç merkezlerinin önemli bir durağ olmaya devam etmiştir. İngiltere'de bu dönemdeki Yahudileri sayılarının az olmasına rağmen ekonomik olarak fakat etkin oldukları bilinmektedir.

1789 Fransız İhtilali ise Yahudiler'in, eşit vatandaşlık haklarına kavuşarak ekonomik haklarını elde etmeleri, Yahudilik'in Fransa'nın resmi dinlerinden kabul edilmesi, devlet düzeni ile dini yapı ve gruplar arasındaki etkileşimin önemli bir aşamasının tamamlanmasını sağlayarak diğer Avrupa ülkeleri için örnek oluşturdu (Roth, A History of The Jews in Britain, 1942, 507).

David Sorkin İngiltere Yahudileri'nin Avrupa Yahudileri'nin iki yüz yılı bulan eşit vatandaşlık haklarına kavuşma mücadelesinde, adım adım ve zaman zaman kazanımların gerilemesine de neden olacak birtakım gelişmelerin de eşlik etmesinin ayrıca değerlendirilmesi gereken bir konu olduğunu vurgulamaktadır (Sorkin, 1992, 81-109).

Yahudi nüfusu bakımından Londra'nın daha fazla ön plana çlkmasına rağmen, XVIII. yy. da Manchester ve Birmingham gibi tekstil şehirlerinin yanısıra, Canterbury, Norwich, Exeter, Liverpool, Bristol, Plymouth, King's Lynn gibi kasabalarda da dikkat çeken sayıda Yahudi varlığından sözediliyordu. İngiltere'de doğan Yahudi çocukların vatandaş kabul edilmesi, fiziksel olmasa da sosyal tepki doğurdu. 
London Committee of Deputies of British Jews -Board of Deputies- (Londra Yahudileri'nin Bağımsızlı̆g 1 Komitesi) Yahudiler'in vatandaşlık problemleri ile ilgili kurumsal çalışmalar başlatmıştı (Roth, England, 754).

Özellikle Birinci Dünya Savaşı sırasında, İngiltere; Amerika Birleşik Devletleri ve Kanada öncesinde önemli bir durak olmuştur. Bu bağlamda Almanya'dan İngiltere'ye göç eden Yahudi bilginlerinin başta Londra olmak üzere, Oxford, Cambridge, Mancheaster, Brighton gibi üniversite kentlerine yerleşmeleri tesadüf değildir.

Sosyolojik değişimlerin Yahudiliğin İngiltere'deki seyrini tarih içinde nasıl şekillendirdiğini temel olarak, David Ruderman ve Todd Endelman'ın çalışmalarından takip etmek mümkündür. İngiltere Yahudiliği ile ilgili çalışmaların önemli bir kısmını, modern düşüncelerin gelişiminin Yahudi felsefesi ve teolojisine olan etkilerini, Almanya, Doğu-Orta Avrupa ve Amerika'daki gelişmelerin etkili bir şekilde takip edildiği, etkin bir medya sisteminin varlığı ile izlemek de bu konu ile ilgili çalışmaları kolaylaştırmakta ve şekillendirmektedir. İngiltere Yahudileri'nin özgürlük arayışları ile direk ilgileri olmasa bile az sayıdaki Yahudi elitlerinin İngiliz yaşamıyla Yahudi hayatı arasında hem pratik hem de zihinsel bir bağ kurdukları söylenebilir. Bu elitlerin başında, Isaac Lyon Goldsmid ve oğlu Francis Henry, Joshua van Oven ve David Salomons gelmektedir (Endelman, 273).

İngiltere Yahudiliği'nin daha sonraki dönemlerde de İsrail Yahudiliği ile çok ilgili olması dikkat çekicidir. Bu durum sadece din bağı ile açıklanamaz. Ekonomik seviyesi yüksek ve iyi eğitimli Yahudiler'in, Avrupa'da, Amerika Birlişik Devletleri öncesi son göç noktası olarak dikkat çeken İngiltere'de oluşturdukları yazılı kültür, modernleşme sürecindeki İngiliz Yahudi tipolojisini anlamamızı kolaylaştırmaktadır. Eğitimli orta sınıf ve ticaretle uğraşan üst sınıfın değer ve yorum üretme fonksiyonlarının aksine, orta alt ve alt gelir grubundaki Yahudiler'in ise dinin pratiğinin şekillenişinin yansıtıcısı ve tanı̆̆ı durumunda olduğunu söylemek mümkündür (Endelman, 275). Almanya, Hollanda, Doğu Avrupa ülkelerinden Amerika öncesi İngiltere'ye doğru oluşu, İngiltere'nin eğitimli Yahudiler için kendilerini ifade etme, iş bulma, dünyadaki diğer Yahudi toplululuk ve coğrafyalarla ilişsili olmak şeklinde açıklanabilir. Birinci ve İkinci Dünya savaşının ise, Yahudi göçlerinin yönünü bir Amerika Birleşik Devletleri ve Kanada olarak değiștirdiği görülmektedir (Endelman, 276).

Yirminci yüzyıldaki Anglo Jewry Ortodoksları'nın dini gelişiminin tarihinde merkezi isim, Louis Jacobs olmuştur. Louis Jacobs'ın New West End Sinagogu içindeki pozisyon mücadelesi, aileden beri taşıdığı muhafazakâr sağ görüşte oluşunun O'nu Hertz sonrası aday olarak tabii olarak güçlendirmektedir.

Dünyanın hemen her köşesine dağılan, kamusal haklarına uzun süreçler sonunda kavuşan, Yahudiler'in şiddetin uygulayıcısı ve önemli bir temsilcisi haline gelmeleri, Sionist eğilimli Yahudiler'in Liberal Yahudiler tarafından sosyo-kültürel ve ekonomik olarak desteklenmesiyle gerçekleşmişti.

İngiltere, Yahudiler'in Orta çağın sonuna doğru ve Avrupa'da en son yerleştikleri ülkelerdendir. Ticari yetenekleri ve uyumlu sosyal davranışlarıyla Yahudiler'in saygınlık ve zenginlik kazanmalarına rağmen, 1222'deki 4. Lateran Konsili sonrası ayrımcllı ile karşı karşıya kaldıklarını görüyoruz. Bu durum Avrupa'nın diğer bölgelerindeki uygulamalar ile karşılaştırıldığında oldukça erken bir döneme rastlamaktadır. 1272 sonrası 1. Edward döneminde Yahudiler, kaybettikleri saygınlık ve ticari haklarını yeniden elde etmişlerdi. 8. Henry Dönemi ise bir duraklama dönemi olarak değerlendirilir. $\mathrm{Bu}$ dönemde İspanya ve Portekiz'deki Yahudiler aleyhindeki uygulamaların İngiltere'ye daha hafif yansıdığı söylenebilir.

XVII. yy. ortalarında ise, Londra'da Marranolar'ın koloniler halinde yaşamaya başladıklarını görüyoruz. Amerika Birleşik Devletleri'ndeki Yahudiliğin Menessah Ben Israel olayı yüzünden sorgulanması, İngiltere Yahudiliği içinde, statü kaybına neden olmuş, Avrupa'nın diğer bölgelerinden daha az haklara sahip bir topluma dönüştürmüştür. Buna rağmen İngiltere ve İrlanda, Kuzey Avrupa'ya doğru Yahudiler'in göç merkezlerinin önemli bir durağı olmaya devam etmiştir. Yahudi bankacıların sayıları az fakat etkin oldukları bilinmektedir. İngiltere'de doğan Yahudi çocukların vatandaş kabul edilmesi, fiziksel olmasa da sosyal tepki doğurdu. Londra'da bu dönemde kurulan, İngiltere Yahudileri'nin Bağımsızlığı Komitesi (London Committee of Deputies of British Jews- Board of Deputies), Yahudiler'in vatandaşlık problemleri ile ilgili kurumsal çalışmalar başlatmıştı. 
Portekiz'den 1497'de tekrar mecbur bırakıldıkları yabancı ve misafir olma durumu, tarihi, tekrarlanan, dini ve hukuki bir durumdur. Matbaanın yaygınlaşmasında başta Venedik olmak üzere Avrupa'daki Yahudi gettoları için yapılan Kutsal Kitap basımları yapmasının önemi büyüktür. Matbaa kullanımında Hıristiyan ve Yahudi nüfusun dini ihtiyaç ve beklentilerinin karşılanmasında başta Kutsal Kitap olmak üzere, İbranice öğretimi ile ilgili kitaplar, önem taşımaktadır. Kutsal metinlerin yaygınlaşması getto Yahudileri'ne kendilerini muhafaza ve ifade etmekle ilgili firsatlar sunmuştur. İngiltere, Almanya, Kuzey Amerika gibi farklı bölgelerde ekonomiyi itekleyen güç, Yahudiler, Luther'i destekleyenler ve Calvinistlerdir.

Yahudilik Luther'den çok önce kendi cemaatlerini özgür saydıkları için reform sonrası ekonomik faaliyetleri alışageldikleri becerileri ile ve yeni koşullara uyum sağlayarak devam ettirdiler. Topluma karşı borçlu hissetmiyor kendi ekonomik faaliyetlerini düzenleme ruhuyla hareket ettikleri için doğal kapitalist olarak görülebilirler. Karl Marx (ö.1883), ticaret ve finans sektörünün anti-sosyal bir faaliyet olduğunu düşünmüştür. Kapitalist kavramıyla Yahudileri vurgulamıştır. İngiltere Yahudileri'nin eleştirildiği ve seküler olarak eleştirilmesine neden olan bu entegrasyon Reformist ve Muhafazakar Yahudilik için uygun koşulların varlığını göstermektedir.

XVIII. yy. sonu ve XIX. yy. başlarına gelindiğinde, Fransa ve Prusya Yahudileri'nin haklarınınarttığını, diğer Doğu Avrupa Yahudileri'nin, dini eşitlik arayışları ile ilgili olarak, aktif taleplerinin olduğunu görüyoruz. Bu dönemde İngiltere Yahudileri için ise neredeyse sessizlik hakimdir. Bunun nedeni olarak, David Vital'in değerlendirmesi, bütün Yahudiler içinde İngiltere Yahudileri'nin sayıca az olmasidir (Clark, 2005, 36).

Güneybatı İngiltere'deki XIX. yy. Yahudi Grupları hakkında yapılan çalışmada İngiltere Yahudiliği' nin İkinci Dünya Savaşına kadar olan süredeki organizasyon ve kurumlarında büyük ölçüde özgür oldukları belirtilmektedir. Bu bölge ile Londra Yahudi sinagoglarındaki uygulamalar büyük ölçüde benzerlikler göstermektedir. İngiltere'deki Yahudi toplumunun tarihi ve dini mirasının yaşatıldığl, Yahudi kimliğini devam ettirmenin önemli bir kaygı olduğunu belirtmek gerekir (Susser, 1993, 16).

Yahudiler, İngiltere'de, siyasi, ekonomik, sosyal ve dini statüleri ile ilgili olarak kısa ara dönemler dışında olumlu bir gelişme seyri tecrübe etmişlerdir. İngiltere'de Yahudilik'e ait Londra, Oxford, Brighton bölgelerinde daha fazla olan Yahudi yerleşimleri bulunmaktadır. XVII. yy. başında İngiltere'de, 100 binden fazla Yahudi'nin yaşadığı tahmin edilmektedir (Roth, 1942, 16).

XVII. yy. ikinci yarısındaki gelişlerinden itibaren, toplu ibadet izni, XIX. yy. dan itibaren Baro'ya kabul edilme, parlamentoya alınma izni alan Yahudiler'in İngiltere toplumu ile uyum içinde olduğu, XIX. yy. sonlarında Doğu Avrupa ülkelerinden yaklaşık yüzyirmi bin Yahudi'nin, yaklaşık yarısının Londra'ya yerleşmek üzere, İngiltere'ye göç ettiği bilinmektedir. XIX. yy. İngiltere'nin ailelerinin finans ve sosyal hayatta Yahudi etkisini temsil ettikleri bir dönemdir. İngilizler'in Güney Afrika ve Avustralya'daki sömürgelerinin kurulmasında Yahudiler'in büyük payının olması ve İngiliz sömürge gemilerinin uzun süre Yahudiler'in elinde bulunması sebebiyle ekonomik yönden (Sombart, 2016, 37) Fransa'da daha fazla hak kazanmış olan Yahudi toplumu, İngiltere'de de benzer taleplerin beklentisi içindeydi. Yahudiler'in kamusal görevlerde yer almaları, Rothschilds ailesinin parlamentoya girmesi bu dönemde gerçekleşti. Yine bu dönemde Sefarad yerine Așkenazi eğilimlerin öne çıkması Doğu Avrupa'dan gelen göçlerle ilişkilidir. Yahudi çocuklarının gittiği okulların ayrışması, Yahudiler'in sosyal hayatta daha uyumlu bireyler haline gelmeleri ve kendi ibadetlerini serbest şekilde yapabilmeleri bu dönemde gerçekleşti (Sombart, 2016, 38).

İngiltere'de Yahudiler'in ondokuzuncu yüzyıldaki mücadele sürecini Grayzel, “Mücadele devam etti ve engelleri ortadan kaldıran bir tasarı Avam Kamarası'ndan birkaç kez $(1833,1834,1836)$ geçmesine rağmen Lordlar Kamarası'nda başarıya ulaşılamadı. Bununla birlikte, aynı yıllarda İngiliz üniversitelerinin kapıları Yahudiler'e açıldı. 1835 yılında David Solomons, 1837 yılında ise Moses Montefiore Londra Şerifi olarak seçildi. Kraliçe Victoria, Moses Montefiore'ye şövalyelik nişanı verdi.1855 yllında ise David Solomons bu defa Londra Belediye Başkanlı̆̆l görevine seçildi. Yahudilerin İngiltere Parlamentosuna girmesini engelleyen yasak ise, Lionel Rothschild ve David Salomons'ın Avam Kamarasına defalarca seçilerek muhaliflere karşı sürdürdükleri uzun ve çarpıcı bir mücadele sonunda 1858 yılında kaldırılmıștır" șeklinde özetlemektedir (Grayzel, 508). 
İngiltere'deki Yahudi toplumu, Hollanda ve Almanya'dan onyedinci yüzyılın ikinci yarısından itibaren gelen Sefardi ve Așkenazi gruplara dayanmaktadır. 1858 yılında Yahudiler'e tanınan özgürlük, İngiltere vatandaşı olarak eşitlik hakları verdiği için çok önemliydi fakat Yahudi kimliği ile ilgili belirsizlik içeriyordu. İngiltere Yahudileri, bütün Avrupa Yahudileri'nin yaşadığı problem olan eşit ve özgür vatandaş ve dini azınlık olma tecrübesi ile yüz yüze geldiler. Bu teorik olarak planlanabilecek bir süreç değildi, deneyimsel olarak Anglo-Yahudilik'in bir alt kültür oluşturma sorumluluğuna evrildiği bir dönemdi (Clark, 2005, 303).

Reformistler ile Ortodokslar arasındaki ayrılma ondokuzuncu yüzyılda daha da netleşmişti. 'Tevrat otoritesinin kutsallığı' tartışması ve 1842 yılında Londra Hahambaşısı'nın Reform Sinagogu'nu yasaklayan bildirisi tarihi bir kırılma noktası oluşturdu (Equinox, 1987,171).

İngiltere'deki Yahudiler'in çoğunluğu orta sınıfı temsil ediyordu. Bu topluluk hakkında 'laik değerlerin baskın olmadığı bir dini grup' tanımlaması M. Freud Kandel'e aittir (Kandel, 2006, 24). Reformist görüşlerin açıkça tartışılması ve taraftar bulmaya başlamasından sonra, Ortodoks Yahudiliğinin korunması ile ilgili kaygıların artması nedeniyle, başhaham pozisyonunun İngiliz Yahudi topluluğundaki rolünün daha da dikkate değer konumda olduğu görülmektedir (Kandel, 2006,24). XX. yy. dinin nasıl düzenlenmesine ait bakış açılarının değiştiği ve çeşitliliğin arttığı görülmektedir (Kandel, 2006, 25). İkinci Dünya Savaşı öncesinde, İngiltere, Avrupa'daki göçlerin odak noktasıdır. Filozof Rabbi Dr. Alexander Altmann (1906-1987), Manchaster Bet-Din'e Rabbi olarak geldi. İngiltere'ye gelen birçok Rabbi, başta Londra olmak üzere farklı şehirlerinde istihdam edildi. Onlar, Ortodoks Rabbiler tarafından dışlanmalarına rağmen, o zamana kadar sınırlandırılan 'progressive conservatism' (gelişim ve yeniliğe açık muhafazakârlık) olarak adlandırılan görüşlerin güçlenmesinde önemli rol oynadılar (Chaim, 1969, 226).

\subsection{Ortodoks Yahudilik}

Londra'da Ortodoks Yahudilere başhahamlık yapan Joseph H. Hertz (1872-1946), Israel Brodie (18951979), Immanuel Jakobovits (1921-1999)'in görevli oldukları dönem, (1800 lü yılların sonu 1960 lı yılların başına kadar) İngiliz Yahudiliği'nin de dönüşümüne rastlamaktadır. Doktrine yönelik eleştiriler ile pratikler için farklı görüşlere-Ateizm, çoğulculuk ve çokdinlilik gibi akımlar- açık olan bu dönemdeki hahambaşlarının farklı karar ve uygulamalarının, sıradan bir Yahudi'nin yaşamını etkilediği kadar, fikri ayrımlara da karşıllk geldiği görülmektedir. Başhaham Dr. J.H. Hertz, İngiliz Yahudileri'ni birarada tutmak için çaba harcamasına rağmen, savaş ve soykırım şartları nedeniyle bu çabalar sonuç vermemiştir. Dr. J. H. Hertz ile Siyonizme destek veren meslektaşı, Robert Waley Cohen'in arası açılmıştı. UOHC (Union of Orthodox Hebrew Congregations)'nin misyonu Hertz'in ölümü ve savaş sonrası Reform ve Liberal Yahudi oluşumları ile zayıfladı. Waley Cohen, 1946 yılında Ortodoks Birleşik Sinagogu (United Synagogue) başkanı oldu (Ceserani, 2005, 200). Bu dönemde Liberal ve Progressive cemaatler ayrıcalıklı vergiye tabi tutuldu. Bu dönemde, İspanya ve Portekiz Yahudi cemaatleri dini lideri ile Birleşik Yahudi Kongresi (United Hebrew Congregations) başhahamının aynı görüşleri dile getirmiş olması, İngiltere'deki Liberal ve Progressive cemaatlerin Avrupa'daki tartışmalar ile yakından ilgilendiklerini göstermektedir. İngiltere'nin özel şartlarından etkilenmelerinin yanısıra, temel tartışmaların Yahudiliğin temel problemlerinin tarihi devamlılık, felsefi gereklilik ve sosyolojik gerçeklikle uyumlu olduğu görülmektedir.

İngiltere Yahudileri'nin özgürlük arayışları ile doğrudan ilgileri olmasa da az sayıdaki Yahudi elitlerinin İngiliz yaşamıyla Yahudi hayatı arasında hem pratik hem de zihinsel bir bağ kurdukları söylenebilir. Bu elitlerin başında, Isaac Lyon Goldsmid ve oğlu Francis Henry, Joshua van Oven ve David Salomons gelmektedir (Endelman, 273).

\section{LOUIS JACOBS'IN HAYATI}

Louis Jacobs, 17 Temmuz 1920 tarihinde İngiltere'nin Manchester şehrinde doğdu. Dedeleri, Litvanya'dan XIX. yy. sonunda İngiltere'ye, Yahudiler'in rahat çalışma şartlarına sahip olduğu için göç eden, Ortodoks Yahudi geleneklerine bağlı bir ailedir. Louis Jacobs, Manchester Yeşivası'na gidene kadar ailesi tarafından, kültürel olarak çevresindeki diğer Yahudi çocukları gibi uyumlu bir şekilde eğitildiğini belirtmektedir (Cosgrove, 2008, 12). 
Louis Jacobs dedesinin Yahudi hukuku ile ilgili sorulara cevap verecek kadar bilgi sahibi olduğunu ve çevresindeki kişilerce Rabbi olarak saygı gördüğünü, babasının ise, Şabat için sinagoga gitmemesine rağmen, dini günlerde aile içinde bugünleri önemseyen geleneksel dini düşünceye saygılı bir kişi olduğunu anlatmaktadır. Kendi ailesini tanıtırken, 'ailem yabancı bir göçmen ailesiyken, İngiliz Yahudisi'ne dönüştü' ifadesini kullanmaktadır. Jacobs, ticaretle uğraşan annesinin amcalarını (Ceserani, 2005) ve işçi olarak çalışan babasını 'liberal' olarak nitelendirmektedir (Jacobs, Helping With Inquiries: An Autobiography, 1989, 11). Siyasi olarak İngiltere'deki Yahudiler, İkinci Dünya Savaşı yıllarında Siyonist-antisiyonist farklılaşmasını belirgin şekilde yaşamaları nedeniyle, İşçi Parti'ye (Labour Party) eğilimli görülmelerine rağmen, genel olarak Muhafazakâr Parti'ye (Conservative) daha yakın olmuşlardır. Louis Jacobs'ın kendi babası hakkında 'hiçbir zaman İşçi Parti'ye oy vermediğini, benzer șekilde bu durumun, İngiliz Yahudi kimliğinin belirgin genel özelliklerinden biri olduğunu belirtmesi dikkat çekmektedir (Alderman, London Jewry and London Politics 1889-1986, 1989, 102).

Louis Jacobs, Manchester Siyonist Yahudileri tarafından oluşturulan Kibbutz'da eğitim gördüğü sırada tanıştığı Shula Lisagorska ile, 28 Mart 1944'te evlendi. Evliliğinden sonra, Siyonist ve Ultra-Ortodoks eğitim kurumlarında dersler verdiği, eşinin ailesi tarafından ekonomik olarak destek aldığı otobiyografisinde yer almaktadır. Yeşiva'da olduğu gibi hergün üç saat Talmud çalışmaya devam ettiği sırada, kendisini saçı uzun, sakalı traşlı olduğu için tuhaf hissettiğini ifade etmektedir. Jacobs'ın eşi Shula'ya göre, hem Litvanya kökenli Doğu Avrupa gelenekleri hem de İngiliz kültürü bu ailede birlikte yaşanmaktaydı (Jacobs, Helping With Inquiries: An Autobiography, 1989, 67). Çocukları Ivor, Naomi ve David'dir. 1974 yllında oğlu Ivor'un yönetiminde New North London Sinagog'u Londra'daki ikinci Masorti Sinagogu olarak faaliyete başlamış olup sinagog hizmet vermeye devam etmektedir.

Louis Jacobs'ın Manchester'da başlayan hayatı, Londra'da devam etmiştir. Louis Jacobs ailesinin Litvanya'dan beri devam eden geleneklerine dair daha iyi ve daha kötü tercihi yapmaksızın, kendi yolunu çizmesi gerektiğine inandığını ifade etmektedir (Cosgrove, 2008, 10).

Louis Jacobs, Manchester'daki Yeşiva ve Tyne'deki Gateshead Kollel ile Londra Üniversitesi'nde eğitim gördü. Louis Jacobs, Bar-Mitzva töreninden sonra kendisine 'Yeşiva'ya gitmek isteyip istemediğini' sorulduğunu, Jacobs'ın tereddütü sırasında genç bir adamın Yeşiva'da öğretmenlik yaptığını anlattığını, ailesinin ise 'neden olmasın' cevabını hatırladığını yazmaktadır (Jacobs, Helping With Inquiries: An Autobiography, 1989, 42). Yeşiva eğitimi sırasında öncelikli olarak Talmud, İbranice gramer ve Yahudi Tarihi dersleri okudu. Fakat Jacobs, Yeşiva'da isteyen öğrencilerin sanat, felsefe gibi dini konular dışındaki alanlara da ders dışı olmak üzere zaman ayırdıklarını belirtmektedir (Jacobs, Helping With Inquiries: An Autobiography, 1989, 28). Louis Jacobs'ın felsefeye olan ilgisinde, küçük yaşta annesi tarafından İngiliz edebiyatı başta olmak üzere geniş bir okuma birikimine sahip oluşu etkilidir. Gateshead Kollel'de iken, Louis Jacobs'ın Talmud çalışmalarından artan zamanda sıklıkla kütüphaneye gittiği bilinmektedir (Jacobs, Helping With Inquiries: An Autobiography, 1989, 47).

Louis Jacobs hocası Rabbi Golditch hakkında, “O’nun çok iyi bir hoca olduğunu, yıllar sonra Hasidilik ile ilgili bu kadar çok yazmasının ve düşünmesinin temelinde Yeşiva'daki aldığı eğitimin ve Rabbi Golditch'in de etkisinin olduğunu" yazmaktadır (Jacobs, Helping With Inquiries: An Autobiography, 1989, 24).

Kollel, Litvanya'da XVIII. yy. sonunda geliştirilen, Talmud'un daha anlaşılır olmasını hedefleyen ileri düzeydeki eğitim kurumudur. Rabbi Dessler ve David Dryan'ın öncülüğünde Litvanya'daki eğitimin İngiltere'de de uygulanabileceği düşünülerek açılır. Yeşiva, dini eğitim vermesine rağmen, Dessler; Yeşiva ile Gateshead arasındaki mesafenin azaltılması için de çaba göstermiştir. Yeşiva, akademik kariyer imkânı sunduğu için Talmud çalışmalarının dünyevi beklenti ve sonuçlar için yapılması eleştirilmiştir. Gateshead Kollel'de, Polonya, Litvanya ve Almanya'dan gelen öğrencilerle birlikte öğrenim gören Jacobs, Rabbi Dessler'in kurucusu olduğu Gateshead Kollel'de, Doğu Avrupa Yahudi ve Alman geleneğinin etkisinin baskın olduğunu, Dessler'in formal olarak çok kısa bir süre hocası olmasına rağmen, K. Marx, C. Darwin (ö.1882), S. Freud (ö.1939) ve A. Einstein'den (ö.1955) yaptığı alıntıların kendisini etkilediğini ve Dessler ile fikri alışverişini yıllar sonra da sürdürdüğünü ifade etmektedir (Jacobs, Helping With Inquiries: An Autobiography, 1989, 59). 
Louis Jacobs, sonraki yıllarda Manchester Yeşivası'nda aldığı eğitiminin, Yahudi Teolojisi çalışmasına temel oluşturduğunu anlatmaktadır (Jacobs, Helping With Inquiries: An Autobiography, 1989, 20). Rabbi Yitzhak Dubov (1887-1977), Louis Jacobs'ın, Hasidi geleneği içinde Habad-Lubovitch ile ilgilenmesini sağlayan kişidir. Rabbi Yitzhak Dubov'un eğitimi sırasında uyguladığı müfredata ek aktivitelerin, sinagog ilahilerinin ibadetlerin coşkunluğunu arttıran etkisinin çocuklardaki vecd duygusunu etkilediğini- Jacobs'ın kendi deyimiyle, 'Talmud yorumları dersinden daha fazla dini duygusunun gelişmesini sağladığını' ifade etmektedir. Habad-Lubovitch geleneğinden bir başka Rabbi Yitshak Rivkin (ö.1947), Jacobs'ın, Rabbani bir koordinasyon kazanmasını sağlamıştır. Jacobs'ın gelecekteki eğilimlerinin temel araçlarını, Hasidi ve Habad temalarındaki analitik çalışmalarını ve özetlemelerini elde etmesinde aynı zamanda Manchester Rabbinik Mahkemesi'nin başında bulunan Rabbi Rivkin'in katkısı önemlidir. Böylece Louis Jacobs'ın düşünce dünyası ilk eğitimi ile geleneksel Ortodoks düşüncesi üzerine gelişmeye başlamıştır (Cosgrove, 2008, 21).

Jacobs, Manchester Yeșivası'nda kendisine arkadaşları tarafından, 'masmid' (uzun süre ara vermeden çalışmaya devam eden) denildiğini, aradan geçen yıllarla birlikte, kendisinin o günlerden oldukça uzakta farklı bir hayatının, üstüste meşguliyetlerinin olduğunu anlatmaktadır (Jacobs, Helping With Inquiries: An Autobiography, 1989, 267).

Louis Jacobs Manchester Sinagogu'ndaki sekiz yıllık eğitiminin ardından 1943 yılında Rabbi ünvanını aldı (Cosgrove, 2008, 19). Bu sırada Manchester'da bulunan Higher Crumpsall Synagogue'nda İbranice sınıfına katıldı, Manchester's Ortodox Labor Zionist hareketinin eğitim faaliyetleri içinde görev yapan, Alexander Altmann ile ortak çalışmalarda yer aldı. Alexander Altmann'ın Londra UCL (Londra Şehir Üniversitesi)'ye döndükten sonra kendisini de daveti, Louis Jacobs'ın felsefe, literatür ve hermenötik alanında kendisini geliştirmesini ve akademik olarak eğitimini devam ettirmesini sağladı. Doktora çalışması sırasında Rabbi Dr. Alexander Altmann (1906-1987) ile Rabbinik, akademik ve kişisel bağlar kurdu. Louis Jacobs, Moses Mendelshon'ın (1729-1786) önemli bir takipçisi ve görüşlerinin Avrupa ve Amerika'da daha iyi tanınmasını sağlayan Altman'ın (1906-1987) görüşlerinden istifade etti. Louis Jacobs'ın doktora çalışmasında, 'The Business Life of the Jews in Babylon From the 3rd to the 6th Century', Yahudi hukuk geleneğinin çevresel etkenlerle olan etkileşimini; dil, teolojik ve ekonomik bakımdan incelediği bu çalışma 'Economic Conditions of the Jews in Babylon in Talmudic Times Compared with Palestine' adıyla yayınlanmıştır (Cosgrove, 2008, 58).

Louis Jacobs gibi Manchester Yeşivası'nda eğitim gören arkadaşı Dayan Moshe Swift (1907-1983), Beth- Din'in başkanı olarak, Louis Jacobs'ı Sinagog'da dinleyiciler önünde teolojik bir tartışma yapmaya davet etti. Louis Jacobs ise bu daveti reddederek, bu konuyu iki kiși arasında konuşmanın daha doğru olduğunu söylemiştir. (Moshe, 300) Dayan Moshe Swift bir konferans sonrası Jacobs'ı, 'topluma Kabala'yı öğretmeye çalışmak' ile suçladı. Bu suçlama, Swift'in sözlü tepkiler almasına yol açtı ancak Jewish Chronicle'da Louis Jacobs'ı savunan bir yazı yayınlandı. (Jacobs, Helping With Inquiries: An Autobiography, 1989, 228) Swift, “çok da tanınmayan bir kişinin açık ve utanmasızca, Tanrı'nın kanununu değiştirmek istediği için Jacobs ile uğraşmak zorunda kaldıklarını, neye mal olursa olsun, İsrail'in ölmemesi için bu heretiklerle mücadeleye devam edeceklerini” açıkladı (Moshe, 302). D. Moshe Swift'in Louis Jacobs'ı Ortodoks Yahudilik'i temsilen kurumsal olarak eleştirdiği görülürken, Jacobs'ın bu durumdan kaçınması kötü niyetli olmasa bile, tepkilerden çekindiği ve bireysel davrandığı sonucunu ortaya çıkarmaktadır.

Londra'da Golders Green'deki Beth Hamidraş'ta bir süre öğretmenlik yaptı. Londra Üniversitesi'nde başlayan akademik çalışmaları da bu yıllara rastlamaktadır. Manchester Central Sinagog'ta Rabbi olarak görev aldı. 1954 yılında, Jew's College müdürü olan Isidore Epstein'in (1834-1962) onayı ile Hillel House Üniversitesinde 'The Talmud, Its Origins, Growth and Redaction' konusundaki kursu Louis Jacobs verdi. Daha sonraki yıllarda İngiltere ve Amerika Birleşik Devletleri'ndeki birçok üniversitede dersler verdi (Kandel, 74).

1954-1959 yılları arasında Londra New West End Sinagogu'nda Rabbi olarak görev aldı. New West End Sinagogu, Kensington'da bulunan St. Petersburg Place'de 1879'de Sir Samuel Montagu tarafindan kurulmuş, United Sinagog'dan ayrılarak Anglo-Jewry bir karakter taşımaktadır. Louis Jacobs'a göre, reform hareketine tepki olarak bölgedeki Yahudiler'in başka sinagoglara kaymasına engel olmak için, Hahambaşı Hermann Adler tarafından tanıtılan birtakım düzenlemeler yapılmakla birlikte aslında 
geleneksel bir çizgidedir. Kadın ve erkeklerin ayrı ayrı oturduğu sinagogun dua korosunun karma olması bu yenilikler arasında sayılmaktadır (Jacobs, Helping With Inquiries: An Autobiography, 1989, 103).

1953 Ekim ayında New West End Sinagogu'ndaki başhahamlık seçimleri için aile dostu Ephraim Levine, Sir Samuel Montagu tarafından kurulan ve İngiliz Yahudiliği içinde varolan reform ve reform karşıtı tartışmalardan etkilenen New West End Sinagogu'na başhaham olması için Louis Jacobs'ı teşvik etmiş ve bu konuda kendisine yardım etmiş, seçimleri kazandığı için duyduğu memnunuiyeti Louis Jacobs'a bir mektupla bildirmiştir (Jacobs, Helping With Inquiries: An Autobiography, 1989, 110). Seçimleri kazanan Louis Jacobs'ın altı yıl sonunda başhaham olması teamüllerin getirdiği bir sonuç olmasına rağmen Louis Jacobs'ın görüşlerinin mercek altına alındığı ve bu seçimin gereğinin gerçekleşmediği bir süreç başlamıştır.

\section{LOUIS JACOBS'IN TEMEL GÖRÜŞLERİ}

Louis Jacobs'ın, geleneksel Yahudilik ile ilgili akademik düşüncelerinin oluşmasında, geleneksel öğrenme ile bilimsel yöntemlerin kullanılması arasında, toplumsal liderlik ile akademik yeterlilik arasında henüz kurulmayan köprülerin kurulabileceğine inanması etkilidir. (Cosgrove, 2008, 6) Jacobs, genel olarak öğrenme kavramının, seküler bir eylem olarak kazanılabileceğini ve dini inançların daha güçlü olmasını sağlayabileceğini de ifade etmiştir. Jacobs Solomon Schechter ve Joseph Hertz gibi düşünürlerden etkilenen Jacobs'ın özellikle G.K. Chesterton (ö.1936), H.G.Wells (ö. 1946) ve G.B.Shaw'un (ö.1950) etkisiyle dil, problemler, popüler ve İngiliz felsefi aklının da etkileri görülmektedir. (Cosgrove, 2008,15)

Altmann'ın etkisi, Jacobs'ın Doğu Avrupa ile İngiliz kökenli doneleri paylaşma ve sentezlemeyi gelenekselleştirmesini sağlamıştır. Jacobs'ın Rabbinik Teolojiyi gözden geçirerek özetlemesi, Talmudî Bilgi konusundaki çalışma ve savunduğu tezleri, Yahudi dogmaları, Yahudi mistisizmi ve Hasidi davranışları, Yahudi hukukunun içeriği ve responsa literatürü, Yahudi Teolojisinin yapısı ile ilgili çalışmalar ve İngiliz Felsefe geleneğinde, O'nun bütün bu alanlardaki çalışmaları, sadece O'na özgü olmasa bile, nadir rastlanan çalışmalardır. Aslında Louis Jacobs'ın çalışmaları Yahudiler ile ilgili tarihteki birikimin ne olduğunu anlamak ve bunun nasıl değerlendirileceği ile ilgili kendi yorumunu ortaya koymak olarak da ifade edilebilir. Louis Jacobs, bu durumu, 'Yahudiliğin bir Yahudi için'nasıl bir tanımlama ve gelenek sunduğunu açıklamak olarak ifade eder. Louis Jacobs, Yahudiliğe içten ve eleştirel bir bakış açısı geliştirmenin dine zarar vermenin aksine Yahudiliğin tarihsel gelişiminin ortaya çıkarılması konusunda yardımcı olacağı görüşündedir. (Cosgrove, 2008,7)

Louis Jacobs, New West End Sinagogu Başrabbi seçimlerini kazanmasına rağmen pozisyonunu bloke etme hakkı bulunan ve yerine Başrabbi olan Israel Brodie hakkında, 'bir meslektaş olarak cesaret verici olduğunu ve Londra Yahudi Topluluğu'na katıldığım sırada, acemi bir kişiye karşı gösterilen özenle bana samimiyetle davrandığını dürüstlükle söylemem gerekir' demektedir. 1 Mart 1964'te, New West End Sinagogu üyeleri olağanüstü toplanarak, Louis Jacobs'ın kazandığı seçimler nedeniyle Rabbi olmak üzere önerilmesine rağmen, veto edildiği oturumda, İngiliz Ortodoks Yahudi topluluğu içindeki tarihsel bir olaya şahitlik ettiler. (Brook, 1989, 148) Chaim I. Maxman'da, Israel Brodie'nin vetosunu 1961 olarak tarihlendirmekte ve iki yll sonra 1963'te New West End Sinagogu'ndan tamamen ayrıldığını belirtmektedir. (Maxman, 2015, 58-71) Israel Brodie, Louis Jacobs'ın New West End Sinagogu'nda çalıştığı 1954-1959 yılları arasında, O'nun düşüncelerinin Rabbi olmak için uygun olmadığını bildiği halde, entelektüel birikimi ve yetenekleri nedeniyle, temel Yahudi inancından farklı olan fikirlerinden vazgeçmesini umduğunu, bu konu ile ilgili olarak Louis Jacobs ile konuştuğunu, sonuç itibariyle Louis Jacobs'ın fikirlerini değiştirmediği gerçeğinden dolayı duyduğu üzüntüyü ifade etmektedir. Konferans, sinagog konuşmaları ve hatıralarını yazan Israel Brodie'nin, Louis Jacobs'ın New London Sinagogu'nu kurduğu dönemle ilgili metinlerinde, 'Ortodoks bir İngiliz Yahudi olmanın önemini geleneksel çizgideki devamlılığın daha da güçlenmesini arzuladı̆̆ı’ ifadeler dikkat çekmektedir (Brodie, 1969, 21).

Chief Rabbi Hertz'in 1946 Eylül ayındaki ölümünden sonra, Birleşik Sinagog'un (United Sinagog) Başkanı, yeni başkanın kim olacagını hemen hemen belirlemişti. Resmi ve gayrı resmi yaklaşım, Hertz gibi, kendi sağlam prensiplerini takip etmek yerine başkalarının tavsiyelerini dinleyecek biri olması 
yönündeydi. Mayıs 1948’e kadar yeni başhaham adayı için bir isim üzerinde anlaşmaya varılamadı. Mayıs 1948'deki konferansda tek isim olarak Israel Brodie ismi üzerine anlaşmaya varıldığı için seçimsiz kazandı. Tek aday olması nedeniyle Brodie'nin görevinde güçlü bir konumu vardı. (Kandel,101)

Louis Jacobs, otobiyografisinde, 'We Have Reason To Believe'de tartışılan vahiy ve geleneği yorumlama konusundaki görüşlerine dair açıklamalara yer vermesine rağmen, New West End Sinagogu'ndaki görevinden ayrılışı ile ilgili olarak Rabbi Brodie'ye dair herhangi bir suçlayıcı ifadeye yer vermemektedir. Jacobs, New West End Sinagogu'ndaki görevli olduğu sırada, Brodie'nin kendisiyle İngiliz literatürü hakkında sohbet ettiğini, fakat yaklaşımlarını dostça bulmadığını belirtmektedir (Jacobs, Helping With Inquiries: An Autobiography, 1989, 108). Dr. Rabbi Isidore Epstein emekli olduktan sonra, Rabbi Israel Brodie, New West End Sinagogu'na bağlı kolej müdürü olarak, görevi gereği sahip olduğu veto yetkisini kullanmış, Louis Jacobs'ın temel görüşlerini heterodoksi olarak nitelendirerek, başhaham olmasına karşı çıkmıştır. (Kandel,104) Bu gelişmeden sonra Louis Jacobs'ın nasıl bir tutum sergileyeceği ile ilgili olarak Amerika, Manchaster ve Oxford'daki arkadaşları ve meslektaşları ile görüş alışverişinde bulunduğu bilinmektedir. (Kandel,102)

Louis Jacobs ile birlikte, 'Progressive Conservative' kabul edilen üçyüz kişi Jacobs'ın New West End Sinagogu'nda seçimleri kazandığı halde Rabbi Israel Brodie tarafından veto edilmesinin ardından, New West End Sinagogu'ndan ayrıldı. Kurucu Rabbi olan Louis Jacobs, 3 Mart 1964'te, St. John's Wood United Sinagogu'na New London Sinagogu adını verdi ve New London Sinagogu'nun kuruluşundan itibaren manevi liderliğini üstlendi. (Alderman, 1992, 363) Louis Jacobs, New West End Sinagogu'ndan ayrıldıktan sonra, 1959-1962 yılları arasında İngiliz Ortodoks Yahudileri'nin eğitim kurumu olan Londra Yahudi Koleji'nde (London Jews College) ders vermeye devam etti. Louis Jacobs kendisini Progressive Conservative olarak değerlendirmediği gibi, Ortodoks Yahudilik ile ilgili eleştirilerine rağmen, kendisinin Ortodoks Yahudilik çizgisinden ayrıldığına dair net açıklamalardan çekinmiştir. Masorti Rabbi olarak kabul edilen Louis Jacobs'ın görüşleri her ne kadar Ortodoks Yahudi Topluluğu içinde tartışılan ve ilk defa dile getirilmeyen görüşler olsa bile, Ortodoks Yahudileri'nin genel kabul gören düşünceleri olmadığı gözönünde bulundurulmalıdır. Ayrıca Louis Jacobs'ın değerlendirmeleri Amerika Birleşik Devletleri'ndeki Jewish Theology Seminery ve çevresinde destekleyen topluluğun görüşleri ile örtüştügü için Jacobs, Muhafazakâr Yahudilik'in İngiltere'deki en önemli temsilcisi kabul edilmektedir. Jacobs'ın New West End London Sinagogu'nda görev yaptığı yıllarında Jewish Chronicle'da yayınlanan ve daha sonra 'Jacobs Affair' olarak isimlendirilen görüşleri, İngiltere Ortodoks Yahudiliği içindeki başlıca zıtlık ve farklılaşmanın simgesi olarak nitelendirilmektedir. (Ceserani, 2005, 217-220)

Louis Jacobs, Will Herberg'in 'vahiy' görüşünü, 'We Have Reason To Believe' de Emil Brunner'in 'gramafon analojisi' ile şu şekilde aktarmaktadır: 'Tanrı'nın kendi sözü üzerine insanın yaptığı müdahalede sessiz kalması, pasif olması, Kutsal Kitab'ın okunana kadar sessiz, kapalı bir kitap oluşu, her şeye rağmen Tanrı sözü olarak kalp ve irade ile hazır halde bulunarak dinlemenin gerektirdiğini hatırlatmıștır. (Jacobs, We Have Reason To Believe, 81)' Louis Jacobs’a göre vahiy değișmiştir. Vahyin maruz kaldığı değişikliklerin kasıtlı olup olmaması tartışmasından önce, Louis Jacobs'a göre, bu durumun gerçekleşmesi de Tanrı'nın onaylaması anlamına gelmektedir. Jacobs'ın dini bilginin niteliği üzerinde durduğu açıkça görülmektedir. 0 , Kutsal Kitap ve dini geleneğin reddedilmemesini sözlü ve yazılı olarak koşulsuz savunan ve bu durumu yaşam felsefesi ve pratiği olarak kabul eden Ortodoks Yahudilerce eleştirilmiş, Reformist Yahudiler tarafından ise ilgiyle karşılanmıştır. Louis Jacobs, 'Yahudiliğin eleştirilmesinde günümüz için gönüllü olunmasının gerekliliğini, genellikle tahakküm etme şeklinde ya da tamamen görmezden gelinmesinin yanlışlı̆̆ını dile getirmektedir'. Kendisinin İngiliz Ortodoks Yahudi Topluluğu çevrelerinde, Amerikan taraftarı olarak yansıtılmaya çalışılmasından rahatsız olmuştur. Çünkü Louis Jacobs hiçbir zaman kendisini Amerikan teolojik düşüncesi içinde değerlendirmekten memnun değildir. (Cosgrove, 2008,183)

Yazdığı eserleriyle Yahudilikle ilgili çok geniş bir alana açılmasına rağmen, Jacobs'ın entelektüel çıkışı ve merkezinin çağdaş İngiltere ile örtüştüğü görülür.1950'li yıllarda ilk eserlerini arka arkaya veren Louis Jacobs'ın antik dönem ile modern dönem çalışmalarına önem verdiğini ve araştırmalarında dini metinler kadar felsefi argümanları da ele aldığını söylemek mümkündür. 1960’lı yılların başında da 
Louis Jacobs, Kuzey Amerika'daki Muhafazakâr Yahudi Toplulukları, yayın şirketleri ve kişilerle, kişisel, akademik ve entelektüel ilişkiler kurmayı başarmıştır. Louis Jacobs üzerinde etkili bir kişilik olan Littman Library'nin sahibi Joesph Littman ve Jewish Chronicle'ın editörü William Frankel (19172008) ile olan iletişiminin güçlü olması, görüşlerini yayınlama konusunda destek bulmasını sağlamıştır. (Jacobs, Helping With Inquiries: An Autobiography, 1989,133)

Altmann'ın kuruculuğunu ve liderliğini yaptı̆̆ı, Yahudilik Çalışmaları Enstitüsü'nden (Institue of Jewish Studies) aynı fikirleri paylaşan arkadaşları da Louis Jacobs'ın görüşlerini desteklemekteydi. Jacobs'ın takipçileri Londra'da, Yahudi Teolojisi Çalışma Topluluğunu (Assossiation of Study Jewish Theology) kurarak, Jacobs'ı kurumun yöneticiliğine getirdiler. Louis Jacobs'ın uzun yıllar ders verdiği ve yöneticiliğini sürdürdüğü bu kurum İngiliz Muhafazakâr Yahudiliği için önemli bir merkez oldu.

'We Have Reason to Believe' (1957), 'JewishValues' (1960), 'Principles ofthe Jewish Faith' (1964), 'Faith' (1968) eserleri arka arkaya yayınlanan Jacobs, Kutsal Kitap'ın modern eleștirilerinin metodunu önemsemekte, sonuçlarını kabul etmekte ve Pentatök'ün tamamının ilhamla yazıldığı görüşünü reddetmektedir. (Jacobs, Helping With Inquiries: An Autobiography, 1989, 145) Louis Jacobs, Kitab-1 Mukaddes'in oluşturulmasında insan faktörünün önemini ifade etmiştir. Aynı zamanda 'Tora min Has MA yim' ilkesi ile Tora'nın ilhamla yazıldığı düşüncesinin çeliştiğini ifade etmiştir. (Jacobs, Helping With Inquiries: An Autobiography, 1989, 146) Louis Jacobs'ın, 1957 yılında yayınlanan 'We Have Reason To Believe' eseri, O'nun teolojik görüşlerini yansıtan ve tanınmasını sağlayan eseri olmuştur.

1955 yılında Louis Jacobs'ın yayınladığı 'Jewish Prayer' ise O'nun bakış açısını vurgulaması açısından önem taşımaktadır çünkü dua konusunu geleneksel bir yöntemle değil, bireysel önemi açısından inceleyen bir argümanla açıklamıştır. Jacobs'ın bireyselliğe yaptığı vurgu, Amerika ve Amerika merkezli yayıncılar ile Ortodoks olmayan Yahudi düşünürlerin dikkatini çekmesini sağlamıştır. Bunlar arasında, Jewish Theological Seminary of America ve Rabbinical Assemblies of America isimli kuruluşlar, Leo Baeck (ö.1956), Hugo Bergmann (ö.1975), Theodor Herzl Gaster (ö.1992) gibi Ortodoks olmayan Yahudilik'in dünyanın önde gelen düşünürleri, Commentary (1945) başta olmak üzere Kuzey Amerikalı yayın grupları sayılabilir.

Louis Jacobs'ın kendisinin ifade ettiği üzere, ‘Teyku' kavramı Jacobs'ın Yahudi inanç ve felsefesini en iyi şekilde özetlemektedir: 'Modern İbranicede Teyku kelimesi beraberlik anlamında yani bir futbol karşılaşmasında iki takımın da gol atamaması ya da iki takımın da eşit sayıda gol atması durumunda kullanılır. Talmud' daki ne zaman geçerse geçsin, beraberlikle biten maçın galibi olmadığı için, kazanan daha sonra oynanacak maç ya da maçlara kalmakta ve sonuç ileri bir tarihe ertelenmektedir. (Jacobs, Teyku: The Unsolved Problem in the Babylonian Talmud, 1981)' Babil Talmudu'nda 'teyku' kelimesi, üçyüz defa tekrar edilmekte iken, Kudüs Talmudu'nda bu kelimeye rastlanmamaktadır (Jacobs, The Talmudic Arguement, 12). Jacobs, Yahudi inancının yapısı hakkındaki görüşleri, sosyo-ekonomik ve kültürel etkileşimlerin Yahudilik üzerindeki bıraktığı izler ile geleneğin idealize ettiği din kavramının birbirlerine karşı durumunu bu kelime ile ifade etmektedir. Dini, ilahi, göksel vahiy, peygamber dönemi dışındaki uygulamalar ile beșerî, ekonomik, coğrafi ve tarihsel diğer koşulların etkisi ile dünyevi unsurların Yahudilik içinde birbirinden daha az olmayan şekilde varlığını, birlikteliğini ve sürekliliğini birinin diğerine göre daha önde olmama durumunu Jacobs, sadece tarihsel bir problem olarak görmemekte, dinin bu konuda dünyevi olana imkân vererek gelişebildiğini realist olarak kabul etmenin zorunluluğunu tartışmaktadır.

\section{SONUÇLAR VE ÇIKARIMLAR}

Rabbi Dr. Louis Jacobs, XX. yy. İngiltere Yahudileri içinde en küçük Yahudi topluluğu olan Muhafazakâr Yahudilik'in temsilcisi olan, Yahudi Teolojisi, Halaha, Yahudi Mistisizmi ve Etiği alanında, yarım asır boyunca eserler veren teolog, din adamı ve filozoftur.

Louis Jacobs, akademik felsefi ve teolojik bağlamda yaptığı çalışmalarını vahiy konusunda epistemolojik tutarlılık veya bir başka ifadeyle vahiy epistemolojisi bağlamında inceleyerek, Modern Kutsal Kitap yorumlarında yararlanarak vahiy konusunda eleştirel yaklaşımı benimsemiştir. Rabbi Jacobs'ın inanç konusunda ise, vahiy konusundaki eleştirel yaklaşımın aksine bireysel dindarlık ve geleneksellik vurgusunu önplanda tuttuğu için, Reformistler'e nispetle Ortodoks Yahudilik'e yakın Muhafazakâr Yahudilik içinde yer almaktadır. 
Louis Jacobs, modern dönemdeki İngiliz Ortodoks Yahudileri içinden kendisini akademik ve fiili olarak ayrıștırarak Muhafazakâr Yahudilik'in İngiltere'deki en önemli temsilcisi olmuştur. Felsefi ve sosyolojik olarak, 'dünyevileşmenin dini tehdidi' tezine karşı samimi ve entelektüel bir çözüm arayışında olan Louis Jacobs'ın Ortodoks Yahudilik'e yönelttiği eleștiriler, seküler bir haham olarak tanımlanması için yeterli değildir.

Louis Jacobs'ın etkin bir din adamı olarak New West End Sinagogu'ndaki Baş Rabbi pozisyonu için mücadele ederken, aynı zamanda Yahudi Teolojisine ait objektif eleştirel görüşlerini özgür bir şekilde ifade etmekten kaçınmaması bu eseri ile özdeşleştirilmektedir. Kazanmış olduğu seçime rağmen, We Have Reason To Believe' deki 'vahyin objektifliği' problemi ile veto edilişi gerekçelendirilmektedir. İngiltere Yahudiliği içinde, New London Sinagogu, Birleşik Sinagog ve Liberal Sinagoglar dışında bir alternatif oluşturmuştur. Londra merkezli ve marjinal bir hareket olarak da değerlendirilebilecek bu oluşum, Kanada ve Amerika Birleşik Devletleri'ndeki Muhafazakâr Yahudilik mensuplarının yüksek oranda oluşu, bu oluşuma ait kurum ve yayınlar ile birlikte değerlendirildiğinde, geleneği reddetmeyen, modernlikle uzlaşmaya önem veren, pratiği reddetmeyen, teolojik tartışmaları felsefi olarak, Yeni Yahudilik Teolojisi ile ilişkilendiren, dinamik bir kurumsallaşma hareketi olduğu söylenebilir. Yahudi Teolojisi, ahlak, ibadet ve toplumsal konulardaki düşüncelerini açılarken Louis Jacobs'ın, Kutsal Kitap eleştirilerindeki bilimsel yöntemi gözardı etmediğini, Tevrat konusundaki tarihsel yorum ve açıklamaları bütüncül olarak ele aldığını ve mutlak yenilikçi Liberal Yahudi görüşler ile katı geleneksel ve sosyal değişmelere kayıtsız Ortodoks Yahudi görüşlerden kendisini uzakta konumlandırarak değil, aksine her ikisini de ama Ortodoks Yahudi görüşleri daha fazla eleștirerek kendi düşüncelerini ifade ettiği görülmektedir. Louis Jacobs Reformist Yahudiler'in Yahudi geleneğini kabul ettiklerini ifade etmelerine rağmen, gelenekten kopuk bir açılama biçimi benimsediklerini, Orta çağ Yahudi düşünürlerine atıf yapmaktan kaçındıkları ve burumda kendi içlerinde çelişkili olduklarını ifade ederek, onları eleştirmiştir. Ortodoks Yahudilik'ten dişlanmış olmalarına rağmen kendisini Ortodoks Yahudilik dışında tanımlamamış olması ilginç olmakla birlikte, vahiy konusundaki görüşleri ve Kutsal Kitap'ı değerlendirmesi ile Ortodoks Yahudilik arasındaki fikir ayrımı açıkça kendisini göstermektedir. Louis Jacobs'ın geleneğin kabul ve devamlılı̆̆ konusundaki görüşleri ise Ortodoks Yahudilik ile örtüşmektedir.

Jacobs, Modernleşmenin kaçınılmazlığını ifade etmekte, Kutsal Kitap'taki metin ve anlam probleminin akıl ile çözümlenirken geleneğin dışlanmamasını gerektirdiğini savunmakta, toplumsal değişim ve dönüşüm süreçlerinin Kutsal Kitap metnine insan unsurlarının katkısını kolaylaştırdığını ve bu durumun akıl ile çözümlenebileceğini, dinin yirminci yüzyılda gerilemesi ve yok olması tezine karşı ayakta oluşunun gelenek sayesinde gerçekleștiğini, din ve dindışı unsurların rekabetinin eşitlik durumunda olduğunu ifade etmektedir.

\section{KAYNAKÇA}

Alderman, G. (1989). London Jewry and London Politics 1889-1986. New Yor: Routledge.

Alderman, G. (1992). Modern British Jewry. Oxford.

Asad, T. (2007). Sekülerliğin Biçimleri. (F. B. Aydar, Çev.) İstanbul: Metis.

Bağır, M. A. Kutsal Kitap Eleștirisi: Eski Ahit ve Modern Dönem Öncüleri. Harran Üniversitesi İlahiyat Fakültesi Dergisi, XIX(31), 279-310.

Brodie, I. (1969). The Strength of My Heart. London: Sermons and Addresses.

Brook, S. (1989). The Clup: Jews of Modern Britain. London: Constable.

Ceserani, D. (2005). The Jewish Chronicle and Anglo Jewry 1841-1991. Cambridge University Press.

Chaim, B. (1969). Troubled Eden. London: Vallentine\&Mitchell.

Clark, M. (2005). Identity and Equality The Anglo- Jewish Community in the Post Emancipation Era. Oxford: Faculty of History.

Cosgrove, E. J. (2008). Teyku: Unsoluable Contradictions in the Life of Thought Louis Jacobs. Chiccago. 
Durkheim, E. (1995). The Elementary Forms of Religious Life. (K. Fields, Çev.) New York: The Free Press.

Eliade, M. (1995). Dinin Anlamı ve Sosyal Fonksiyonu. (M. Aydın, Çev.) Konya: Din Bilimleri.

Eliade, M. (2000). Dinsel İnançlar ve Düşünceler Tarihi. (A. Berktay, Çev.) İstanbul: Kabalcı.

Endelman, T. Jews of Georgian.

Endelmann, T. (2002). The Jews of Britain 1656 to 2000. London.

Equinox, N. D. (1987). Yahudi Dünyası. İstanbul: İletişim.

Ettinger, S. (1997). A History of The Jewish People. Cambridge: Harvard Universty Press.

Friedman, R. E. (2004). Kitab-ı Mukaddesi Kim Yazdı? (M. Tarakçı, Çev.) İstanbul: Kabalcı.

Gürkan, S. L. (2008). Yahudilik. İsam.

Hazard, P. (1999). Batı Dünyasındaki Büyük Değişme. (E. Güngör, Çev.) İstanbul : Ötüken.

Jacobs, L. (1981). Teyku: The Unsolved Problem in the Babylonian Talmud. New Jersey: Corrnwall Books Leo Beack College.

Jacobs, L. (1989). Helping With Inquiries: An Autobiography. Vallentine\&Mitchell.

Jacobs, L. (1990). God, Torah, Israel. Cincinnati: The Efrayemson Lecture Hebrew Union College Press.

Jacobs, L. (1995). The Jewish Religion: A Companion. Oxford Universty Press.

Jacobs, L. (1999). Beyond Reasonable Doubt. London.

Jacobs, L. (1984). The Talmudic Arguement.

Jacobs, L. (1957). We Have Reason To Believe.

Jonathan, I. (1998). European Jewry in the Age of Merchantilism 1550-1750. London.

Kandel, M. F. (2006). Ortodox Judaism on Britain Since 1913. Oxford: Oxford University Press.

Katz, S. (1975). Jewish Philosophers. New York: Bloch Publishing Company .

Kurt, A. O. (2010, Ocak-Nisan). Yahudi Aydınlanma Hareketi Haskala. Milel ve Nihal, 7, 35-59.

Kurt, A. O. (2015). Babil Keldani Çin Hint İran İbrani Gelenekleri. İstanbul: İnsan.

Lipinsk, E. J. Revelation, Encyclopedia Judaica.

Louis, D. N. (1999). Contemporary Jewish Thought. Oxford University Press.

Maxman, C. I. (2015). Halakhic Change vs Demographic Change American Orthodoxy and The Plight of Louis Jacobs. Journal of Modern Jewish Studies, 14(1), 58-71.

Petuchowski, J. J. (tarih yok). Reform Judaism, Encyclopedia Judaica.

Robert, G. G. (1990). The Emergence of Jewish Theology in America. USA: Indiana Univesity Press.

Roth, C. (1942). A History of The Jews in Britain.

Roth, C. (tarih yok). England. Encyclopedia Judaica (Cilt 6, s. 754).

Ruderman, D. (2010). Erken Modern Dönem Yahudi tarihi. İstanbul: İnkılap .

Salihoğlu, M. (2011). Marronalar ve Dini İnançları. Ekev, XV(49), 105-115.

Sombart, W. (2016). Yahudiler ve Modern Kapitalizm. (S. Gürses, Çev.) Küre.

Sorkin, D. (1992). Jewish Emancipation in Central and Western Europe in the Eighteenth and Nineteenth Centruies. D. Englander içinde, David Englander. London: The Open University.

Spiro, R. (1992). Post-Biblical Jewish History-The Long Vista, The Jewsih Enigma içinde. (D. Englander, Dü.) London: The Open University. 
Susser, B. (1993). The Jews South-West England. Exeter University Press.

Vogel, M. H. (1978). Monotheism, Encylopedia Judaica, JerusalemJerusalem.

Weinfeld, M. (1978), Covenant, Encylopedia Judaica, Jerusalem.

Wertheimer, J. (2007). The Perplexitities of Conservative Judaism. American Jewish Committee, 124(2), 38-44.

www.jewishvirtuallibrary.org/jewish-population-of-the-world. (2016).

www.worldjewishcongress.org 